\title{
Marine Macroalgae Bioextract Changes the Index of Reflectance in Pepper Plants
}

\author{
Paulo César de Melo ${ }^{1 *}$, Carlos Godinho de Abreu², Kiril Bahcevandziev ${ }^{3}$ and Leonel Pereira ${ }^{4}$ \\ ${ }^{1}$ Department of Agriculture, Federal University of Lavras, Brazil \\ ${ }^{2}$ Department of Biology, Federal University of Lavras, Brazil \\ ${ }^{3}$ Research Centre for Natural Resources (CERNAS) Environment and Society, Institute of Applied Research, Portugal \\ ${ }^{4}$ Department of Life Sciences, University of Coimbra, Portugal
}

Submission: February 02, 2020; Published: March 02, 2020

Corresponding author: Paulo César de Melo, Department of Agriculture, Federal University of Lavras, Brazil

\begin{abstract}
In recent years, marine organisms have received attention for being a source of natural compounds, enabling the creation of a new and promising field of study. Marine macroalgae are a vast source of raw materials and biologically active molecules used in the pharmaceutical, cosmetic, food and agricultural industries. Due to its importance, the present study aimed to assess whether the bioextract of the red macroalgae Kappaphycus alvarezii acts as a biostimulant in the metabolism of plants and changes the reflectance indexes. In particular, the biological activity of the red macroalgae bioextract was focused on stimulating plant growth and photosynthetic activity. A scientific experiment was carried out using a red marine macroalgae bioextract applied on the pepper culture (Capsicum annuum L.). The pepper culture was chosen due to its high sensitivity to stress, generating good responses in the evaluation of the biostimulant and anti-stress capacity of an algal bioextract. The fresh mass of the aerial part and the length of the aerial part were evaluated, and a metabolic evaluation was also performed, represented by the photosynthetic rate produced by the pepper plants.
\end{abstract}

Kewords: Seaweed; Kappaphycus alvarezii; Chlorophyll a and b; Biostimulant; Capsicum annuum

\section{Introduction}

Pepper is one of the five crops with the largest plantation area under a protected cultivation, both in Brazil and in several countries, mainly due to the increase in productivity, fruit quality and obtaining good market prices. Pepper (Capsicum annuum L.) is a perennial Solanaceous plant grown as an annual crop. The largest world producers are Mexico, the United States, Italy, Japan, India and Brazil [1]. Chlorophylls are responsible for collecting the energy contained in photons from sunlight, and for its transduction, in the form of electrochemical potential through photosynthetic membranes, which ultimately serve to reduce atmospheric $\mathrm{CO}_{2}$ to twenty-two carbohydrates. Therefore, the light energy absorbed by the leaves can only be transferred to the biochemical stage of photosynthesis through processes mediated by chlorophylls. The levels of chlorophylls and carotenoids in the leaves are used to estimate the photosynthetic potential of plants, due to their direct connection to the absorption and transfer of light energy and, consequently, with their acclimatization and growth in different environments [2].

Abiotic stress can alter key physiological constituents and functions in green plants. Improving the capacity to monitor this response in a non-destructive manner is of considerable interest, as it would offer a direct means of initiating timely corrective action. Given the vital role that plant pigments play in the photosynthetic process and general plant physiological condition, their accurate estimation would provide a means to monitor plant health and indirectly determine stress response [3]. The interest in marine macroalgae arises due to its advantages such as rapid growth, production of a large volume of biomass and also due to the exclusive characteristics of its polysaccharides/derived compounds such as the physical-chemical, rheological, biological 
properties, in addition to the chemical composition formed by rare sugars, which make it possible to provide extracts with relevant activities when administered to agricultural crops [4].

\section{Materials and Methods}

A portable device for non-destructive estimates of chlorophyll (Chl) content "ClorofiLog", brand "Falker", was used, that allows to identify the state of crops in a simple and direct way [5]. In summary, this device measures the green color index in the leaves that correlates with the chlorophyll content. Large concentrations of nitrogen in mesophilic cells can be in the chloroplast and thus, correlations between the values obtained by the chlorophyll meter and leaf nitrogen can be made [6]. The experimental design consisted of using a plant species (Capsicum annuum L.), a bioextraction of the red macroalgae Kappaphycus alvarezii, in 5 treatments $(0 \%, 0.5 \%, 1.0 \%, 1.5 \%$ and $2.0 \%)$ and 3 repetitions for each treatment, using a substrate composed of ravine soil $(60 \%)$, sand $(30 \%)$ and tanned bovine manure $(10 \%)$, whose chemical composition of the substrate used: $\mathrm{pH}$ 6.3; contents of K (Potassium) - 649.07 mg.dm ${ }^{-3}$; P (Phosphorus) - 27.02 mg.dm ${ }^{-3}$; Ca (Calcium) - 0.95 cmolc.dm $^{-3} ; \mathrm{Mg}$ (Magnesium) - 0.10 cmolc.dm

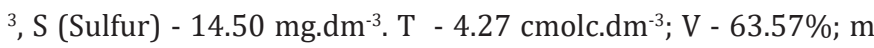
- 24.93\%; MOS - 2,55 dag. $\mathrm{kg}^{-1}$; Prem (Phosphorus) - 17.45 mg.L

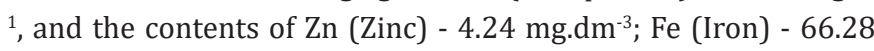
mg.dm ${ }^{-3}$; Mn (Manganese) - 6.62 mg.dm ${ }^{-3}$; Cu (Copper) - 1.74 mg.dm ${ }^{-3}$; B (Boron) - 0.04 mg.dm ${ }^{-3}$; and the contents of Clay - $42 \%$, Silt - 3\% and Sand - 55\%.
The pot capacity was $4.5 \mathrm{dm}^{3}$, two plants per pot. The fertilizations after transplanting the seedlings and for top dressing fertilizations were according to the plant demands, a soluble formulation NPK (Nitrogen, Phosphorus, Potassium) 8-11-38 plus $\mathrm{Mg}-1.6 \%$ and S -2.9\%, B - was applied in fertigation. $0.02 \%, \mathrm{Cu}-0.004 \%, \mathrm{Fe}-0.2 \%, \mathrm{Mn}-0.04 \%$, Mo $-0.004 \%$, Zn $0.02 \%$, Ammonium Sulfate, Calcium Nitrate and Potassium Chloride, for vegetables production. The treatments were $\mathrm{T} 1$ Control without Algal Bioextract; T2 - 0.5\% Alga Bioextract; T3 - 1.0\% Algal Bioextract; T4 - 1.5\% Algal Bioextract and T5 - 2.0\% Algal Bioextract. Evaluation of the fresh green matter and length of the aerial part and was done a metabolic study, performed by the photosynthetic rate produced by the pepper plants. The experiments took place at the greenhouse of the Department of Agricultural Engineering - DEA; Federal University of Lavras UFLA, Minas Gerais, Brazil.

\section{Results and Discussion}

The content of the reflectance index, measured as total chlorophyll, was proportional to macro nutrients, such as nitrogen. Table 1 presents the results of the Photosynthetic Rate, Fresh Matter of the Aerial Part (FMAP) and Length of the Aerial Part (LAP) of the Pepper plants. The highest reflectance index value was found for the T4 treatment - 1.5\% Algal Bioextract (2 foliar applications), total chlorophyll of $685 \mathrm{mg} \cdot \mathrm{m}^{-2}$, followed by the T2 treatment - Algal Bioextract $0,5 \%$ (2 applications via leaf) total chlorophyll of $670 \mathrm{mg} \cdot \mathrm{m}^{-2}$, and the lowest value for treatment T1 - Control, with a total chlorophyll content of $603 \mathrm{mg} \cdot \mathrm{m}^{-2}$.

Table 1: Results of photosynthetic rate, Chlorophyll ( $\mathrm{Chl} \mathrm{a}$ and $\mathrm{Chl} \mathrm{b),} \mathrm{Total} \mathrm{Chl}(\mathrm{a}+\mathrm{b})$ and $\mathrm{Chl}$ a / b ratio (average of 3 repetitions / treatment), Fresh Matter of the Aerial Part (FMAP) and Length of Aerial Part (LAP). Average of 3 repetitions/treatment of pepper plants.

\begin{tabular}{|c|c|c|c|c|c|c|c|}
\hline Treatment & Repetitions & FMAP (g) & $\begin{array}{l}\text { LAP } \\
\text { (cm) }\end{array}$ & $\begin{array}{c}\text { Chl a } \\
\left(\mathbf{m g} \cdot \mathbf{m}^{-2}\right)\end{array}$ & $\begin{array}{c}\text { Chl b } \\
\left(\mathbf{m g} \cdot \mathbf{m}^{-2}\right)\end{array}$ & $\begin{array}{c}\text { Chl a/b } \\
\left(\mathrm{mg} \cdot \mathrm{m}^{-2}\right)\end{array}$ & 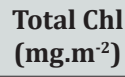 \\
\hline $\mathrm{T} 1$ & 3 & 104 & 50 & 420 & 183 & 2,3 & $603 b^{*}$ \\
\hline $\mathrm{T} 2$ & 3 & 236 & 87 & 449 & 221 & 2,0 & $670 \mathrm{a}$ \\
\hline $\mathrm{T} 3$ & 3 & 186 & 89 & 419 & 186 & 2,3 & $605 \mathrm{~b}$ \\
\hline $\mathrm{T} 4$ & 3 & 109 & 56 & 446 & 239 & 2,0 & $685 \mathrm{a}$ \\
\hline T5 & 3 & 94 & 62 & 429 & 186 & 2,3 & $615 a b$ \\
\hline
\end{tabular}

${ }^{*}$ Averages followed by the same lowercase letter do not differ by Tukey's test at $5 \%$ probability.

When applying the treatment T4 - Algal Bioextract 1.5\% versus $\mathrm{T} 1$ - Control in these plants, showed an increase of $13.5 \%$ in the Total Chlorophyll Index, corroborated by the mean of the Fresh Matter of the Aerial Part (FMAP) of the T2 treatment Algal Bioextract $0.5 \%$ (2 foliar applications) in the amount of $236 \mathrm{~g}$, which was $269 \%$ higher than the Average Fresh Matter of the Aerial Part (FMAP) of the T1 treatment - Witness, which presented a value of $104 \mathrm{~g}$, as well as the average length of the aerial part (LAP) of the T2 treatment - Algal Bioextract 0.5\% (foliar, 2 applications), was $87 \mathrm{~cm}$ higher by $74 \%$ than the value of the Aerial Part length (LAP) of the T1 treatment - Control, which was $50 \mathrm{~cm}$, which can be explained by the biostimulating effect of the Kappaphycus alvarezii Bioextract on plant growth and metabolic activity.
Therefore, portable chlorophyll readers use non-destructive, simple and instantaneous principles, enabling ontogenic foliar studies of cultures. Thus, the values obtained are proportional to the levels of leaf chlorophyll and are called the chlorophyll meter index [7]. Mota [8], working with the application of a brown algae extract resulted in an increase in chlorophyll concentrations (relevant in terms of photosynthetic potential) in treated leaves compared to untreated leaves, proposing that this increase in chlorophyll is due to the betaines present in the algae extracts.

\section{Conclusion}

As a conclusion of this technical-scientific work, the green color index in the leaves of pepper plants, which is correlated 
with the chlorophyll content in the leaves, and which increases the photosynthetic rate, what are the result of the biostimulant activity of the Kappaphycus alvarezii Bioextract, in the culture of pepper (Capsicum annuum L.).

\section{Acknowledgment}

We thank the financial support of the company "Nutri Fertilizantes Indústria e Comércio Agropecuário - LTDA. NUTRIMAX. CNPJ: 00.497.089 / 0001-43; Av. Perimetral Norte, Quadra 20 LT $11 \backslash 12$, 7427. Jardim Diamantina, Goiânia - GO, Brazil". Leonel Pereira works is financed by national funds through FCT - Foundation for Science and Technology, I.P., 410 within the scope of the project UIDB/04292/2020 - MARE - Marine and Environmental Sciences Centre.

\section{References}

1. Silva MAG Da, Boaretto AE, Melo AMT De, Fernandes HMG, Scivittaro WB (1999) Rendimento e qualidade de frutos de pimentao cultivado em ambiente protegido em funcao do nitrogenio e potassio aplicados em cobertura. Scientia agricola 56(4): 1199-1207.
2. Rego GM, Possamai E (2006) Efeito do Sombreamento sobre o Teor de Clorofila e Crescimento Inicial do Jequitiba-Rosa.

3. Shah SH, Houborg R, Mccabe MF (2017) Response of Chlorophyll, Carotenoid and SPAD-502 Measurement to Salinity and Nutrient Stress in Wheat (Triticum aestivum L.). Agronomy 7(3): 61.

4. Pereira L, Bahcevandziev K, Joshi NH (2019) Seaweeds as plant fertilizer, agricultural biostimulants and animal fodder. In: CRC Press, Taylor \& Francis Group, Boca Raton, Florida Pp. 425.

5. Salla L, Rodrigues JC, Marenco RA (2007) Teores de clorofila em arvores tropicais determinados com o SPAD-502. Revista Brasileira de Biociencias 5(2): 159-161.

6. Carvalho MAF, Silveira PM, Santos AB (2012) Utilizacao do Clorofilometro para Racionalizacao da Adubacao Nitrogenada nas Culturas do Arroz e do Feijoeiro. Comunicado Tecnico. EMBRAPA Santo Antonio de Goias, GO Tecnico.

7. Argenta G, Silva PRF Da, Bortolini CG, Forsthofer EL, Strieder ML (2001) Relacao da leitura do clorofilometro com os teores de clorofila extraivel e de nitrogenio na folha de milho. Revista Brasileira de Fisiologia Vegetal 13(2): 158-167.

8. Mota M (2014) Utilizacao de extratos de algas como suplemento nutritivo em fruticultura. Hortofruticultura \& Floricultura

\begin{tabular}{|l|}
\hline \multicolumn{1}{|c|}{ Your next submission with Juniper Publishers } \\
- Quality Editorial service \\
- Swift Peer Review \\
- Reprints availability \\
- E-prints Service \\
- Manuscript Podcast for convenient understanding \\
- Global attainment for your research \\
- Manuscript accessibility in different formats \\
( Pdf, E-pub, Full Text, Audio) \\
- Unceasing customer service \\
Track the below URL for one-step submission \\
https://juniperpublishers.com/online-submission.php \\
\hline
\end{tabular}

